\title{
Perkembangan Transaksi Bisnis E-Commerce terhadap Pertumbuhan Ekonomi di Indonesia
}

\author{
Eri Yanti Nasution
}

eriyanti@umsu.ac.id

Fakultas Ekonomi dan Bisnis Universitas Muhammadiyah Sumatera Utara

\author{
Prawidya Hariani \\ prawidyahariani@umsu.ac.id \\ Fakultas Ekonomi dan Bisnis Universitas Muhammadiyah Sumatera Utara
}

\section{Lailan Safina Hasibuan}

lailansafina@umsu.ac.id

Fakultas Ekonomi dan Bisnis Universitas Muhammadiyah Sumatera Utara

Wita Pradita

praditawita@yahoo.com

Fakultas Ekonomi dan Bisnis Universitas Muhammadiyah Sumatera Utara

\begin{abstract}
Abstrak
Teknologi Informasi dan Komunikasi (TIK) sudah menjadi kebutuhan di zaman sekarang ini, banyak masyarakat di Indonesia yang sudah memanfaatkannya dalam kehidupan sehari-hari. Dinamika perekonomian tidak terlepas dari perkembangan serta kemajuan teknologi, infrastruktur, produktifitas dan inovasi. Kemajuan ilmu pengetahuan memberikan dampak dalam kemajuan teknologi. Disruptive innovation menciptakan pasar sendiri yang berlanjut pada sektor bisnis digital $(E$ commerce). Perkembangan teknologi juga diiringi dengan perkembangan cara menyampaikan informasi dalam berkomunikasi sehingga aktivitas menjadi lebih cepat dengan menggunakan internet dengan aplikasi sosial media. Penelitian ini bertujuan untuk analisis deskriptif perkembangan E-Commerce melalui dan mengestimasi pengaruh bisnis sektor E-Commerce terhadap pertumbuhan ekonomi Indonesia periode 2007-2016. Data yang digunakan dalam variabel ini adalah data sekunder yang diambil dari Badan Pusat Statistik, APJII (Asosiasi Pengguna Jasa Internet Indonesia). Hasil penelitian dengan menggunakan model time serries dengan tehnik OLS (Ordinary Least Square) menunjukkan perkembangan peningkatan bisnis E-commerce cukup besar dalam mendukung pertumbuhan sektor telekomunikasi dan informasi yang memberikan kontribusi sebesar 8\% dari total GDP Indonesia ditahun 2016. UMKM yang menjadi tulang punggung ekonomi Indonesia juga menunjukkan potensinya untuk berperan dalam menggerakkan ekonomi digital nasional. Variabel GDP, Jumlah Pengguna internet (JPI) berpengaruh positif dan signifikan terhadap Pertumbuhan Ekonomi di Indonesia, begitu juga dengan Jumlah Nilai Transaksi e-Commerce (JNTE) berpengaruh positif dan signifikan terhadap pertumbuhan ekonomi pada era digital.
\end{abstract}

Kata Kunci Domestic product, E-Commerce, Pertumbuhan Ekonomi 


\section{JESYA}

JURNAL EKONOMI \& EKONOMI SYARIAH

Jurnal Ekonomi \& Ekonomi Syariah Vol 3 No 2, Juni 2020

E-ISSN : 2599-3410 | P-ISSN : 2614-3259

DOI : https://doi.org/10.36778/jesya.v3i2.227

\section{PENDAHULUAN}

Dinamika perekonomian tidak terlepas dari perkembangan serta kemajuan teknologi, infrastruktur, produktifitas dan inovasi. Ilmu pengetahuan yang terus berkembang memberikan dampak terhadap kemajuan teknologi yang semakin canggih. Inovasi yang dimunculkan dari teknologi memberikan kemudahan dan manfaat untuk manusia dalam beraktivitas. Perkembangan teknologi juga diiringi dengan perkembangan cara menyampaikan informasi dalam berkomunikasi yang dikenal dengan istilah Teknologi Informasi dan Komunikasi ( TIK).

Perkembangan TIK pada masa prasejarah hanya menggunakan bahasa isyarat dan terus berkembang hingga pada tahun 1876 Alexander Graham Bell mengirimkan surat pertama melalui telepon. Sejak saat itu TIK terus mengalami perkembangan sampai akhirnya internet muncul pada tahun 1969 yang dibentuk oleh Departemen Pertahanan Amerika, U.S. Defense Advance Research (DARPA) dengan tujuan keperluan militer untuk menghubungkan daerah atau wilayah vital, progam riset ini adalah Advanced Research Project Agency Network yang lebih dikenal dengan nama ARPANET. Secara umum, internet adalah sebuah jaringan komputer yang saling terhubung dengan menggunakan suatu sistem standar global TCP/IP yang digunakan sebagai protokol pertukaran paket dalam melayani miliaran pengguna yang terdapat diseluruh dunia.

Pada era modern seperti sekarang ini, perkembangan TIK telah membuat masyarakat sekarang dimudahkan oleh berbagai macam bentuk teknologi dan inovasi yang memungkinkan mereka untuk melakukan aktivitas ekonomi dalam skala global. Perkembangan jaringan komunikasi internet menjadi penghubung keseluruhan unit dan membuat komunikasi secara individual ataupun organisasi mudah dan lebih cepat diseluruh dunia. Keterbatasan sarana, waktu dan jarak dapat teratasi dengan canggihnya teknologi komputer dan jaringan internet.

Seiring berkembangannya teknologi telah merubah gaya hidup manusia di dunia termasuk Indonesia,pola pikir masyarakat Indonesia yang masih tradisonal juga perlahan-lahan berubah untuk menyerap tenaga kerja dari sektor pertanian, ke sektor industri dan kini ke sektor informasi dan komunikasi, hal ini juga tidak terlepas dari perkembangan internet di Indonesia. Teknologi pun telah banyak dimanfaatkan dalam berbagai bidang diantaranya perdagangan, perusahaan, perbankan, pendidikan dan kesehatan yang akan lebih efisien dan memangkas biaya. Dalam kegiatan perdagangan perubahan penggunaan media informasi menyebabkan pergeseran dan perubahan paradigma sistem perdagangan tradisional menjadi sistem perdagangan elektronik. Bentuk perdagangan elektronik ini mengarah pada transaksi jual beli barang dan jasa secara online yang dikenal dengan istilah $e$-Commerce.

Perkembangan e-Commerce awalnya pada tahun 1994, IndoNet hadir sebagai internet service provider pertama, saat itu jaringan internet di Indonesia lebih dikenal sebagai paguyuban network dimana semangat kerjasama, kekeluargaan dan gotong royong sangat hangat dan terasa diantara pelakunya. Kehadiran internet di Indonesia menjadi pembuka kesempatan dan peluang pemanfaatan TIK dalam segala bidang termasuk perdagangan. Pada awalnya, internet digunakan sebagai media komunikasi, promosi, dan pertukaran informasi tidak sebagai tempat untuk melakukan transaksi jual beli. Pada tahun 1996 hadir situs jual beli bhinneka.comnamun hanya memperkenalkan profil perusahaan saja dan toko buku online pertama sanur.com, pada saat itu konsumen hanya dapat melihat barang yang diinginkan tetapi proses jual beli masih dilaksanakan secara konvesional. Meski sempat dilanda krisis moneter tahun 1997, pada tahun 1999 bhinneka.com muncul sebagai situs jual beli, kemudian mucul forum diskusi onlinekaskus, muncul juga portal berita detik.com.

Tahun 2000-an sektor e-Commerce terus bertumbuh yang umumnya situs jual beli produk seperti glodokshop.com, datakencana, fastncheap, lipposhop, iklanbaris.co.id, gadogado.net. Namun karena besarnya persaingan satu persatu e-Commerce diberbagai bidang 


\section{JESYA}

JURNAL EKONOMI \& EKONOMI SYARIAH

Jurnal Ekonomi \& Ekonomi Syariah Vol 3 No 2, Juni 2020

E-ISSN : 2599-3410 | P-ISSN : 2614-3259

DOI : https://doi.org/10.36778/jesya.v3i2.227

mulai berjatuhan, hal inilah yang kemudian menjadi awal dari marketplace seperti tokopedia, tokobagus.com yang sekarang telah dilebur menjadi olx Indonesia hingga tahun 2010 sampai sekarang kehadiran go-jek menjadi terobosan mengenai besarnya dampak e-Commerce di Indonesia. Go-jek mampu melayani kebutuhan calon penumpangnya yang tersebar luas. Permintaan yang besar seperti ini dahulu nyaris tak terlayani oleh para pelaku usaha seperti jasa ojek. Hal ini bahkan sampai menarik perhatian e-Commerce luar negri untuk masuk ke indonesia seperti zalora, lazada, shopee dan lain-lain.

Pada tahun 2014 tokopedia berhasil menjadi yang pertama menerima investasi sebesar Rp.1,2 triliun dari Sequoia Capital dan SoftBank Internet and Media Inc (SIMI) yang merupakan angka terbesar dalam sejarah e-Commerce di Indonesia dan pada tahun 2017 tokopedia kembali menerima investasi sebesar USD 1,1 milyar dari Alibaba. Investasi yang baru diterima tokopedia pada tahun 2017 oleh Alibaba Group dengan partisipasi dari pemegang saham tokopedia yang sekarang, menjadikan Alibaba Group sebagai pemegang saham minoritas di tokopedia. Kerja sama dengan Alibaba akan meningkatkan skala dan kualitas pelayanan tokopedia kepada para penggunanya, sekaligus mempermudah para penjual dan tokopedia untuk mengembangkan usahanya ke seluruh nusantara bahkan hingga ke penjuru dunia. Hal ini membuktikan bahwa kemajuan teknologi digital memungkinkan terjadinya perubahan dibanyak bidang. Kegiatan e-Commerce yaitutidak hanya jual beli barang dan jasa secara online tetapi ada industri lain didalamnya seperti penyediaan jasa pengiriman barang atau logistik, produksi perangkat pintar, periklanan, provider telekomunikasi dan lain - lain.

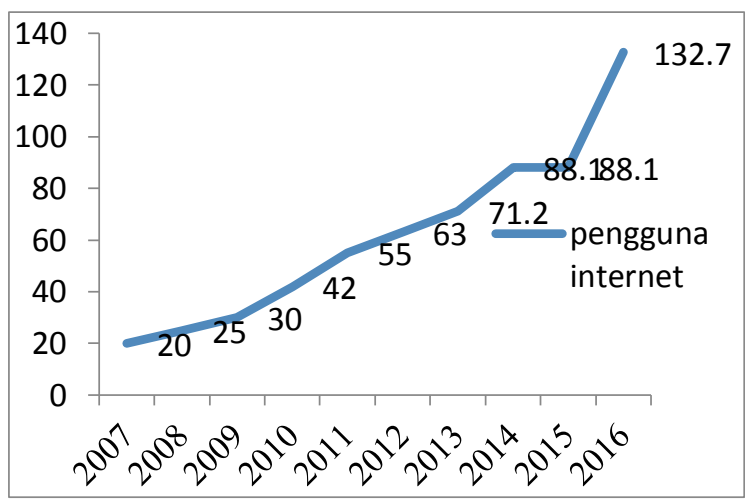

\section{Gambar 1-1 Jumlah Pengguna Internet di Indonesia tahun 2007-2016 (Juta Jiwa)} Sumber : APJII -2016

Dari gambar di atas, pengguna internet di Indonesia mengalami peningkatan dari tahun ketahun hingga pada juni 2017 menurut Asosiasi Penyelenggara Jasa Internet Indonesia (APJII) yaitu sebuah lembaga yang berkaitan dengan perkembangan teknologi digital, tren pengguna internet di Indonesia sebanyak 132,7 juta jiwa meningkat sebesar 44,6 juta jiwa dari tahun 2015 ini juga yang membuat Indonesia menempati negara kelima sebagai pengguna internet terbanyak didunia. Indonesia adalah negara berkembang dengan total penduduk sebanyak 256,2 juta penduduk pada tahun 2016, ini berarti sudah hampir separuh dari total penduduk Indonesia yang menggunakan internet baik untuk komunikasi, sosial media, browsing, hiburan maupun bisnis. Dilihat dari meningkatnya pengguna internet menunjukkan masyarakat nya yang sudah mulai melek dengan perkembangan teknologi dan mulai memanfaatkan teknologi dengan bijak. Kesiapan masyarakat terhadap ekonomi digital 
membuat peran ekonomi digital sangat berpotensi bagi negara Indonesia untuk mengembangkan kegiatan e-Commerce.

Menurut Kementrian Kominfo presentase pengguna internet untuk e-Commerce berdasarkan umur pada tahun 2016, yang tertinggi berada pada umur 26-35 sebanyak 32\%. Hal ini memperlihatkan generasi di Indonesia sekarang atau yang disebut juga generasi millenial mendominasi pengguna internet untuk e-Commerce.

Menurut Stillman dalam bukunya Generasi Z (2018), bahwa generasi millennial adalah generasi yang lahir dalam kurun waktu akhir tahun 1980 sampai 1994 dengan populasi 82 juta orang. Sedangkan Gen-Z yang lahir dalam kurun waktu 1995-2012 jumlah populasinya telah mencapai 72 juta orang. Generasi ini adalah tonggak masyarakat di masa depan. Generasi millennial lahir di era yang dapat dikatakan generasi ini adalah generasi postemotional. Sifat yang dominan adalah optimisme akan kemungkinan tanpa batas yang melahirkan kata kunci dari generasi millennial, yang lebih dikenal dengan passion.

Gen-Z tentu berbeda dengan generasi millenial, Gen-Z tidak bisa diperlakukan sama dengan generasi millenial. Karena generasi mereka ini lahir pada masa teknologi sudah berkembang terutama smartphone, mereka tidak pernah terlepas dari penggunaan smartphone dan akses internet yang sepertinya sudah menjadi kebutuhan, kedua generasi tersebut dianggap berbeda karena dapat mengubah pemikiran dan perilaku pengguna internet dengan kemampuannya menciptakan fenomena lahirnya ekonomi baru dibanding dengan generasi sebelumnya sebagai dampak perkembangan teknologi.

Era internet aktivitasnya didominasi dengan populasi usia produktif dan akan menjadi momentum bagi perkembangan e-Commerce di Indonesia, apalagi Indonesia adalah negara berkembang dengan Bonus Demografinya, yang ditandai dengan masyarakat yang semakin konsumtif tidak lagi didasari pada kebutuhan tetapi didorong oleh hasrat dan keinginan. Perilaku konsumtif ini artinya masyarakat akan meningkatkan daya beli apalagi dengan fasilitas yang sudah semakin mudah untuk berbelanja dan tanpa hambatan. Dengan adanya $e$ Commerce masyarakat perlahan lahan mulai bergeser perilaku aktivitas ekonominya dengan lebih menyukai belanja online, mulai dari belanja pakaian, belanja makanan sampai belanja kebutuhan rumah tangga telah banyak tersedia di perdagangan elektronik. Hal ini di karenakan belanja online lebih banyak pilihan dan tidak membuang waktu serta harganya tidak jauh beda dengan harga yang ada dipasar belum lagi promo yang sering ditawarkan yang akan menarik minat konsumen. Hanya dengan "klik" konsumen bisa mendapatkan dan mengetahui barang yang diinginkan, dan dapat dengan mudah melakukan transaksi dengan siapa saja tanpa dibatasi dengan kendala ruang dan interaksi secara langsung, apalagi perkembangan teknologi smartphone yang menjadi salah satu penunjang dalam dunia bisnis online dan juga semakin banyaknya $e$-Commerce situs jual beli yang semakin membuat konsumen banyak pilihan untuk berbelanja.

Tabel 1-2. Sepuluh BesarJumlah Pengunjung E-Commerce di Indonesia 2017 (dalam Juta)

\begin{tabular}{|c|l|c|}
\hline No & \multicolumn{1}{|c|}{ Nama brand } & $\begin{array}{c}\text { Jumlah } \\
\text { Pengunjung }\end{array}$ \\
\hline 1 & Lazada.co.id & 112.137 .744 \\
\hline 2 & Tokopedia.com & 110.837 .101 \\
\hline
\end{tabular}


Jurnal Ekonomi \& Ekonomi Syariah Vol 3 No 2, Juni 2020

E-ISSN : 2599-3410 | P-ISSN : 2614-3259

DOI : https://doi.org/10.36778/jesya.v3i2.227

\begin{tabular}{|c|l|c|}
\hline 3 & Bukalapak.com & 78.066 .411 \\
\hline 4 & Blibli.com & 51.974 .718 \\
\hline 5 & Shopee.co.id & 25.736 .356 \\
\hline 6 & Jd.co.id & 14.465 .925 \\
\hline 7 & Blanja.com & 9.996 .819 \\
\hline 8 & Zalora.co.id & 8.434 .069 \\
\hline 9 & Elevenia.co.id & 8.153 .083 \\
\hline 10 & Bhinneka.com & 6.305 .923 \\
\hline
\end{tabular}

Sumber : www.iprice.co.id

Berdasarkan tabel diatas, menurut Iprice ( iPrice Indonesia adalah situs perbandingan harga, voucher, kupon, dan promo 2019), produk untuk kebutuhan dari beragam onlineshop dengan daftar yaitu sebuah portal yang menyampaikan informasi yang jelas dan menyeluruh dengan kategori toko online di Asia. Lazada dan Tokopedia bersaing di posisi puncak, dimana Lazada dengan jumlah pengunjung sebanyak 112.137.744 orang telah melakukan kunjungan untuk melihat promosi online, mulai dari promo anniversary di bulan Maret, promo bulan ramadhan saat bulan Juni dan promo Hari Belanja Online Nasional (Harbolnas). Shopee berhasil memasuki daftar 5 besar e-Commerce dengan jumlah pengunjung sebanyak 25.736.356 orang akibat program promosi yang sering dilakukan. Di posisi terakhir yaitu Bhinneka.com dengan jumlah pengunjung sebanyak 6.305.923, bhinneka.com adalah salah satu e-Commerce tertua yang berada di Indonesia yang berhasil bertahan sampai sekarang.

Beberapa bisnis e-Commerce diatas adalah contoh dari perusahaan e-Commerce yangberhasil memanfaatkan peluang pasar yang sedang naik daun ditambah lagi pengguna internet yang semakin meningkat di Indonesia. Perkembangan e-Commerce yang cukup baik di Indonesia tidak lain disebabkan juga oleh pelaku e-Commerce dan belanja online di Indonesia yang memberi dukungan terhadap ekonomi digital. E-Commerce juga diharapkan mampu menjadi instrumen penting bagi ekonomi digital, tidak hanya membantu pertumbuhan usaha kecil dan menengah, tetapi juga petani dan nelayan didaerah.

\section{Tabel Total Penjualan Onlinedi Indonesia ( dalam Milyar USD)}

\begin{tabular}{|c|c|}
\hline Tahun & Penjualan \\
\hline 2012 & 1,04 Milyar \\
\hline 2013 & 1,8 Milyar \\
\hline 2014 & 2,6 Milyar \\
\hline 2015 & 3,56 Milyar \\
\hline 2016 & 4,49 Milyar \\
\hline
\end{tabular}

Sumber : www.statista.com 


\section{JESYA}

JURNAL EKONOMI \& EKONOMI SYARIAH

Jurnal Ekonomi \& Ekonomi Syariah Vol 3 No 2, Juni 2020

E-ISSN : 2599-3410 | P-ISSN : 2614-3259

DOI : https://doi.org/10.36778/jesya.v3i2.227

Berdasarkan tabel di atas, Statista adalah salah satu perusahaan statistik terkemuka di internet yang menyediakan informasi statistik bagi pengguna untuk meneliti data kuantitatif. Total penjualan online di Indonesia dari tahun 2012 sampai tahun 2016 mengalami tren peningkatan. Meskipun besar pendapatan penjualan online belum sebanding dengan penjualan retail tetapi penjualan online mengindikasikan kenaikan dan cukup stabil. Pada tahun 2012 total penjualan online di Indonesia sebanyak USD 1,04 milyar diakibatkan $e$-Commerce belum terlalu populer di Indonesia apalagi jika dilihat dari jumlah pengguna internet tahun 2012 hanya sebanyak 55 juta orang, tidak sebanding dengan jumlah penduduk sebanyak 245,4 juta jiwa. Pada tahun 2016 total penjualan online berhasil meraih sebanyak USD 4,49 milyar, jika dilihat besarnya peluang bisnis e-Commerce yang sangat cepat dengan melihat potensi dan pemanfaatannya dalam kegiatan ekonomi menarik perhatian banyak pihak dalam mengambil bagian dan bahkan melakukan investasi yang fantastis.

Pelaku Usaha Mikro Kecil Menengah (UMKM) tidak lagi menjadi pelaku UMKM tetapi membangun start up. Start up berbeda dengan UMKM, usaha ini menggunakan teknologi internet. Start up mempunyai ambisi untuk menjadi besar dan untuk menjadi pemain global. Di banyak negara, bisnis start up diyakini berdampak penciptaan lapangan kerja yang besar sehinga mereka diberikan ruang dan area khusus dengan kebijakan yang harmonis. Tentu saja anak muda menyambut dengan baik, namun justru sebagai ancaman bagi satu generasi diatas mereka yang menyebabkan kecemburuan terhadap kelompok inovatif. Teknologi telah membuat segala produk menjadi jasa. Jasa yang serba digital dan membentuk marketplace, platform baru dengan masyarakat yang sama sekali berbeda. Menurut Kasali dalam bukunya distruption (2017), banyak bisnis lama yang sudah mapan menjadi goyah setelah berhadapan dengan lawan tak terlihat yang baru misalnya terguncangnya matahari dan ramayana sebagai retailer konvesional ketika berhadapan dengan lazada atau zalora. Saat dunia berubah industri lama terdisrupsi karena lawan-lawan berada diluar jangkauan radar mereka. Sejumlah pihak bahkan menuding daya beli masyarakat turun padahal yang terjadi bukan tentang penurunan daya beli melainkan soal perpindahan cara membeli dan apa yang dibeli konsumen, disruptionlah salah satu penyebabnya.

Sejalan dengan hal itu ilmu ekonomi memandangnya sebagai sebuah transformasi yang tidak bisa dihindari namun tetap harus diwadahi. Salah satu cara untuk mendukung kegiatan $e$ Commerce yaitu dengan upaya inovasi pemanfaatan TIK, mengurangi biaya, meningkatkan kualitas infrastruktur, dan memperluas jaringan melalui TIK.Dalam hal ini pemerintah berperan penting untuk mendukung kegiatan e-Commerce, salah satu bentuk pemerintah mendukung e-Commerce yaitu dengan membentuk UU ITE ditahun 2008.

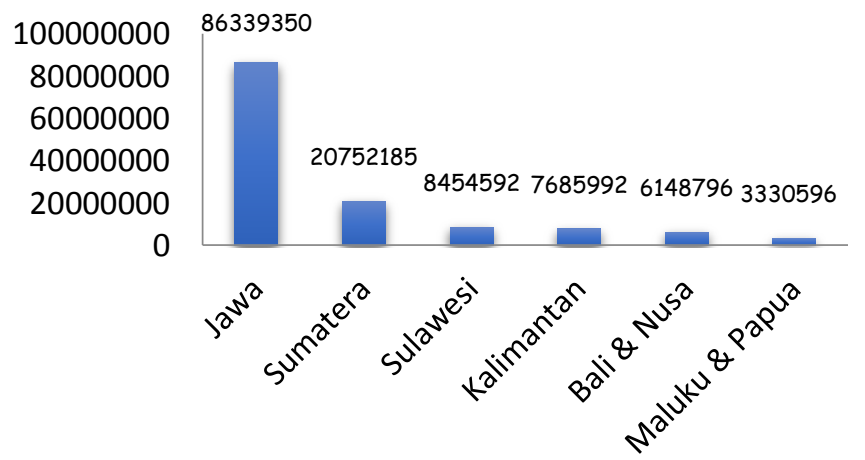

Gambar 1-2. Penyebaran Pengguna internet di Indonesia berdasarkan pulau tahun 2016 (dalam Juta)

Sumber : APJII tahun 2017 


\section{JESYA}

JURNAL EKONOMI \& EKONOMI SYARIAH

Jurnal Ekonomi \& Ekonomi Syariah Vol 3 No 2, Juni 2020

E-ISSN : 2599-3410 | P-ISSN : 2614-3259

DOI : https://doi.org/10.36778/jesya.v3i2.227

Meskipun pengembangan infrastruktur komunikasi juga sudah mulai diperbaiki oleh pemerintah dengan mendukung operator internet di Indonesia, serta penetrasi jaringan $3 \mathrm{G}$ pada tahun 2006, tetapi dapat dilihat dari data penyebaran pengguna internet berdasarkan pulau di Indonesia diatas bahwa pengguna internet masih banyak berada pada masyarakat perkotaan karena mayoritas pengguna internet di Indonesia yang tinggal diwilayah kota yakni di pulau Jawa (terutama di kota-kota besar seperti Jakarta, Surabaya, Bandung, Medan dll).

Pemerintah melalui Kementrian Komunikasi dan Informasi (Kemkominfo) mengakui telah terjadi kesenjangan dalam hal pembangunan dan pengembangan sarana telekomunikasi diantara Pulau Jawa dan luar Pulau Jawa. Namun kesenjangan dalam hal pembangunan infrastruktur telekomunikasi tersebut bukanlah sepenuhnya kesalahan pemerintah. Karena, pengembangan infrastruktur berbasis teknologi informasi itu mayoritas justru dikelola oleh pihak swasta untuk kepentingan bisnis.

Karena itu pemerintah berkomitmen dalam bentuk rencana pitadigital untuk memberi kesempatan agar masyarakat di daerah rural dapat mengakses internet untuk membuka peluang yang sangat positif, tidak hanya bagi masyarakat di daerah rural tetapi jugakepada para pengusaha provider.Menurut menkominfo, masih ada 114 ibukota daerah yang belum terhubung melalui jaringan pita lebar (broadband). Untuk membangun broadband didaerah, pemerintah mulai melakukan kerja sama dengan badan usaha termasuk operator melalui proyek palapa ring. Proyek palapa ring adalah proyek semacam jalan tol yang sedang dibangun pemerintah agar jaringan telekomunikasi nasional bisa menjangkau seluruh kabupaten/kota di 33 provinsi di Indonesia.

Selain proyek palapa ring pemerintah juga akan mendukung masuknya jaringan 4G didaerah yang direncanakan selesai pada tahun 2019. Diharapkan dengan adanya proyek tersebut akselerasi pertumbuhan dan pemerataan pembangunan melalui ketersediaan infrastuktur jaringan telekomunikasi berkapasitas besar bisa memberikan jaminan layanan internet berkecepatan tinggi kewilayah yang sulit tercapai jaringan. Tetapi permasalahan yang ada didesa tidak hanya isu ketersediaan infrastruktur komunikasi saja tetapi sarana dan prasarana pendukung kualitas dan pola hidup masyarakat.Dalam mewujudkan target Indonesia menjadi negara ekonomi digital, pemerintah akhirnya merilis peta jalan sistem perdagangan elektronik atau roadmape-Commerce dan menjadikannya paket kebijakan ekonomi ke-14. Roadmape-Commerce tersebut akan dijadikan landasan pembanguan e-Commerce untuk menyelesaikan berbagai persoalan. Menurut APJII, permasalahan utama yang dihadapi $e$ Commerce yakni keengganan pengguna internet untuk berbelanja online karena banyaknya penipuan dan masalah pembayaran karena tak memiliki kartu kredit atau debit.

Oleh sebab itu pemerintah merilis roadmap e-Commerce yang berisi 8 aspek roadmape-Commerce yaitu pendanaan, perpajakan, perlindungan konsumen, pendidikan dan sumberdaya manusia, logistik, infrastuktur komunikasi, cyber security, dan pembentukan manajemen pelaksana. Roadmape-Commerce diharapkan semakin dapat mendorong kreasi , inovasi dan kegiatan ekonomi baru dikalangan generasi muda.

Meskipun nantinya kepercayaan pembeli akan bertambah karena sistem keamanan telah dibantu namun pro kontra mengenai kebijakan roadmape-Commerce mengenai perpajakan karena pemerintah menetapkan pembayaran pajak $1 \%$, meski hanya $1 \%$ namun bagi sebagian umkm dan pelaku $e$-Commerce terlalu berat. Peraturan pajak juga jangan sampai menghambat pelaku kegiatan e-Commerce yang masih baru berkembang karena infrastruktur yang disediakan oleh pemerintah pun belum memadai terutama didaerah rural. Pemberlakuan pajak juga bisa membuat pelaku bisnis pindah ke media sosial yang nantinya akan semakin sulit dilacak oleh pemerintah. Sebenarnya ada atau tidaknya roadmap, e-Commerce akan 
terustumbuh jika dilihat dari banyaknya pengguna internet di Indonesia. Berdasarkan latar belakang masalah diatas, maka dapat diidentifikasi masalah sebagai berikut :

1. Perkembangan TIK telah menyebabkan perubahan perilaku ekonomi masyarakat Indonesia yang ditandai dengan fenomena perkembangan bisnis yang berbasis internet atau $e$-Commerce.

2. Meningkatnya pengguna internet sebanyak 132,7 juta pada tahun 2016 , tetapi pengguna internetnya masih belum banyak memanfaatkan peluang pasar $e$-Commerce.

3. Perkembangan e-Commercedi Indonesia, ternyata dapat mempengaruhi pertumbuhan ekonomi Indonesia, khususnya sektor perdagangan dan jasa.

4. Melihat perkembangan e-Commerce menunjukkan pertumbuhan positif yang berpotensi untuk pasar $e$-Commerce dimasa depan, tetapi dapat mengurangi usaha-usaha yang masih tetap menggunakan pola pikir tradisional.

5. Kebijakan yang dikeluarkan pemerintah justru dapat menghambat pertumbuhan ekonomi pada sektor e-Commerce.

\section{TINJAUAN TEORITIS}

\section{Model Pertumbuhan Solow}

Model pertumbuhan Solow dirancang untuk menunjukkan bagaimana pertumbuhan persediaan modal, pertumbuhan angkatan kerja, dan kemajuan teknologi berinteraksi dalam perekonomian, serta bagaimana pengaruhnya terhadap output barang dan jasa suatu negara secara keseluruhan dalam (Mankiw, 2006).

Kemajuan teknologi memiliki banyak dimensi:

1. Dapat menghasilkan kuantitas output yang lebih besar dengan kuantitas modal dan tenaga kerja tertentu.

2. Dapat menghasilkan produk yang lebih baik.

3. Dapat menghasilkan produk baru.

4. Dapat menghasilkan variasi produk yang lebih besar.

Dalam setiap kasus konsumen menerima lebih banyak jasa. Jika mempertimbangkan output sebagai serangkaian jasa dasar yang disediakan oleh barang yang diproduksi dalam ekonomi, kemajuan teknologi menimbulkan peningkatan output untuk suatu jumlah modal dan tenaga kerja tertentu. Dapat dipertimbangkan tingkat teknologi (state of technology) sebagai variabel yang memberitahu seberapa banyak output yang dapat diproduksi berdasarkan jumlah modal dan tenaga kerja tertentu pada waktu tertentu. Jika tingkat teknologi dinyatakan dengan A, maka dapat ditulis fungsi produksi sebagai:

$$
Y=\mathrm{F}(\mathrm{K}, \mathrm{AN}) \text {. }
$$

Persamaan ini menyatakan bahwa produksi bergantung pada modal dan pada tenaga kerja dikalikan tingkat teknologi. Memperkenalkan tingkat teknologi dengan cara ini akan membuatnya lebih mudah untuk berpikir mengenai pengaruh kemajuan teknologi terhadap hubungan antara output, modal dan tenaga kerja. Persamaan 2.1 menyiratkan bahwa kita dapat memikirkan kemajuan teknologi dalam dua cara yang ekuivalen :

1. Kemajuan teknologi mengurangi jumlah pekerja yang diperlukan untuk memproduksi sejumlah output tertentu.

2. Kemajuan teknologi meningkatkan output yang dapat diproduksi dengan sejumlah pekerja tertentu. Kita dapat mempertimbangkan AN sebagai jumlah tenaga kerja yang efektif (effective labor) dalam ekonomi. Jika tingkat teknologi A berlipat ganda, seolah-olah ekonomi memiliki pekerja dua kali lebih banyak. Dengan kata lain, kita dapat 
mempertimbangkan output diproduksi oleh dua faktor: modal $(\mathrm{K})$ dan tenaga kerja yang efektif (AN).

Dengan mengasumsikan pengembalian pada skala konstan: untuk tingkat teknologi tertentu (A), penggandaan baik jumlah modal $(\mathrm{K})$ maupun jumlah tenaga kerja $(\mathrm{N})$ mungkin akan menimbulkan penggandaan output. (Blanchard dan Johnson, 2014).

Modal per pekerja efektif $\mathrm{k}$ adalah konstan dalam kondisi mapan. Karena $\mathrm{y}=\mathrm{f}(\mathrm{k})$, maka output per pekerja efektif juga konstan. Dengan adanya kemajuan teknologi, model ini akhirnya bisa menjelaskan kenaikan yaitu menunjukkan bahwa kemajuan teknologi bisa mengarah kepertumbuhan yang berkelanjutan dalam output per pekerja. Mengacu pada model Solow, hanya kemajuan teknologi yang bisa menjelaskan peningkatan standar kehidupan yang berkelanjutan (Mankiw,2006).

\section{Teori Pertumbuhan Endogen}

Untuk menggambarkan gagasan dibelakang teori pertumbuhan Endogen, dimulai dengan fungsi produksi sederhana :

$$
\mathrm{Y}=\mathrm{A} \cdot \mathrm{K}
$$

Dimana :

$\mathrm{Y}=$ output

$\mathrm{K}=$ Persediaan Modal

$\mathrm{A}=$ Konstanta yang mengukur jumlah output yang diproduksi untuk setiap unit modal.

Fungsi produksi ini berkaitan dengan pertumbuhan ekonomi. Diasumsikan sebagian pendapatan ditabung dan diinvestasikan. Karena itu, dijelaskan akumulasi modal dengan persamaan yang telah kita gunakan sebelumnya:

$$
\Delta K=s Y-\delta K
$$

Dimana :

$\Delta K=$ perubahan persediaan modal

sY = investasi

$\delta=$ depresiasi

Menggabungkan persamaan ini dengan fungsi produksi $\mathrm{Y}=\mathrm{A} . \mathrm{K}$, maka didapat :

$\Delta \mathrm{Y} / \mathrm{Y}=\Delta \mathrm{K} / \mathrm{K}=\mathrm{sA}-\delta$

Persamaan ini menunjukkan apa yang menentukan tingkat pertumbuhan output $\Delta \mathrm{Y} / \mathrm{Y}$. Selama $\mathrm{sA}>\delta$, pendapatan perekonomian tumbuh selamanya, meskipun tanpa asumsi kemajuan teknologi eksogen. Dalam model Solow, tabungan akan mendorong pertumbuhan untuk sementara, tetapi pengembalian modal yang kian menurun pada akhirnya akan mendorong perekonomian mencapai kondisi mapan dimasa pertumbuhan hanya bergantung pada kemajuan teknologi eksogen. Sebaliknya, dalam model pertumbuhan Endogen, tabungan dan investasi bisa mendorong pertumbuhan yang berkesinambungan.

Menurut (Todaro, 1999) teori pertumbuhan yang baru menyajikan suatu kerangka teoretis untuk menganalisis apa yang disebut sebagai pertumbuhan Endogen atau proses pertumbuhan GNP yang bersumber dari suatu sistem yang mengatur proses produksi. Kontras dengan teori neoklasik tradisional,model-model pertumbuhan Endogen menyatakan bahwa pertumbuhan GNP itu sebenarnya merupakan suatu konsekuensi alamiah atas adanya ekuilibrium jangka panjang.

\section{METODE PENELITIAN}

Metode penelitian ini berisi langkah-langkah melakukan penelitian dan teori-teori yang cukup relevan terhadap suatu masalah yang dianalisis. 
Penelitian ini bertujuan untuk mengestimasi dan menganalisis hubungan antara variabel dengan menggunakan model ekonometrika dengan data kuantitatif. Data kuantitatif yaitu data yang berbentuk angka dan bilangan, kemudian diolah dan dianalisis untuk diambil kesimpulan. Variabel-variabel yang diamati adalah variabel-variabel yang terdapat pada periode tahun penelitian. Data time series yaitu data yang terdiri atas satu objek tetapi meliputi beberapa periode waktu. Variabel-variabel yang diamati adalah variabel-variabel yang terdapat pada Pertumbuhan Ekonomi (PE) yang dipengaruhi oleh Gross Domestic Product (GDP), Jumlah Nilai transaksi e-Commerce (JNTE) (JPOS), Jumlah Pengguna Internet (JPI).waktu penelitian yang dihimpun adalah pada tahun 2007-2016.

Sumberdata yang digunakan dalam penelitian ini adalah data sekunder yang sudah dipublikasi oleh institusi resmi pemerintah Indonesia dan non-pemerintah. Sumber data diperoleh dari data BPS, Kominfo, Bank Indonesia (BI), Asosiasi Penyelenggara Internet Indonesia (APJII) dan akses internet yang terkait.

\section{Model Estimasi}

Model estimasi yang digunakan untuk melihat bagaimana variabel yang berhubungan dengan transaksi dengan E-Commerce yang mempenagruhi pertumbuhan ekonomi Indonesia. dengan menggunakan model time series yang meliputi beberapa periode waktu yakni pada tahun 2007-2016. Variabel-variabel yang diamati adalah variabel-variabel yang terdapat pada Pertumbuhan Ekonomi (PE) yang dipengaruhi oleh Gross Domestic Product (GDP), Jumlah Nilai Transaksi e-Commerce (JNTE) di Indonesia, Jumlah Pengguna Internet (JPI). Maka modal ekonometrik yang akan digunakan dalam penelitian ini adalah sebagai berikut :

\begin{tabular}{|c|c|}
\hline PEt & $=$ Pertumbuhan Ekonomi pada tahun $\mathrm{t}$ \\
\hline GDPt & $=$ Gross Domestic Product pada tahun $\mathrm{t}$ \\
\hline JNTEt & $=$ Jumlah Nilai Transaksi E-Commerce pada tahun $\mathrm{t}$ \\
\hline JPI & $=$ Jumlah Pengguna Internet pada tahun $\mathrm{t}$ \\
\hline$\alpha_{0}$ & $=$ Konstanta \\
\hline $\begin{array}{l}\alpha_{1}, \alpha_{2}, \alpha_{3} \\
\varepsilon \mathrm{i}\end{array}$ & $\begin{array}{l}=\text { Parameter dari setiap variabel bebas } \\
=\text { Error Term }\end{array}$ \\
\hline
\end{tabular}

Adapun metode estimasi yang digunakan dari penelitian ini, menggunakan metode regresi data cross section pada model pertama dan time series pada model kedua maka penelitian ini akan menggunakan teknik metode regresi linear berganda dengan tehnik OLS (Ordinary Least Square) utuk melakkukan pembuktian bagaimana variabel tersebut mempengaruhi pertumbuhan ekonomi.

\section{HASIL DAN PEMBAHASAN \\ Hasil}

Koefisien determinasi (Adjusted R-squared) berarti proporsi presentase variabel total dalam menjelaskan variabel terikat yang dijelaskan oleh variabel bebas secara bersama-sama. Berdasarkan dari model estimasi diatas yaitu variabel-variabel yang mempengaruhi pertumbuhan ekonomi maka diperoleh nilai $\mathrm{R}^{2}$ sebesar 0,542166 atau $54 \%$ artinya secara bersama-sama variabel gross domestic product, jumlah nilai transaksi e-Commerce, jumlah pengguna internet memberi variasi penjelasan terhadap laju pertumbuhan ekonomi sebesar 
$54,22 \%$ dan sisanya $45,88 \%$ dijelaskan oleh variabel diluar model estimasi, atau berada didalam disturbance error term.

Koefisien korelasi (R) menunjukkan kuat atau tidaknya suatu hubungan linier (derajat hubungan) antara variabel bebas dengan variabel terikat. Besarnya koefisien korelasi dari hasil running data untuk model estimasi ini sebesar 0.694778 atau 69\%. Artinya secara bersamasama variabel gross domestic product, jumlah nilai transaksi e-Commerce, jumlah pengguna internet memiliki derajat hubungan sebesar $69,48 \%$ (sangat tinggi) terhadap pertumbuhan ekonomi, dan sisanya 30,52\% derajat hubungannya variabel diluar model estimasi, atau berada diluar model estimasi atau pada disturbance error term.

Jumlah pengguna internet sangat mempengaruhi jumlah nilai transaksi semakin besarnya jumlah pengguna internet maka kemungkinan semakin besar pula jumlah nilai transaksi yang dilakukan secara online yang dapat mempengaruhi sumbangan sektor TIK dalam pembangunan ekonomi yang dilihat dari besarnya sumbangan GDP. Berbagai aktivitas ekonomi dilakukan untuk dapat meningkatkan penghasilan dan pendapatan untuk mengimbangi kemajuan teknologi dan pola hidup modern terutama untuk menggerakkan trend ekonomi digital. Hasil running data dengan menggunankan software EViews versi 8 dapat dilihat pada tabel berikut ini :

\section{Tabel 3-1. Hasil Analisis Regresi Model Estimasi Pertumbuhan Ekonomi}

Dependent Variable: PE

Method: Least Squares

Date: 03/21/18 Time: 03:16

Sample: 20072016

Included observations: 10

\begin{tabular}{lrlll}
\hline \hline \multicolumn{1}{c}{ Variable } & Coefficient & Std. Error & t-Statistic & Prob. \\
\cline { 3 - 5 } \multicolumn{1}{c}{ C } & 46.63303 & 20.16788 & 2.312243 & 0.0601 \\
LGDP & 3.713015 & 1.672037 & -2.220654 & 0.0681 \\
LJNTE & 0.080064 & 0.173572 & 0.461275 & 0.0608 \\
\multicolumn{1}{c}{ LJPI } & 0.716804 & 0.270179 & 2.653071 & 0.0379 \\
\hline \hline R-squared & 0.694778 & Mean dependent var & 1.727430 \\
Adjusted R-squared & 0.542166 & S.D. dependent var & 0.126147 \\
S.E. of regression & 0.085355 & Akaike info criterion & -1.794812 \\
Sum squared resid & 0.043713 & Schwarz criterion & -1.673778 \\
Log likelihood & 12.97406 & Hannan-Quinn criter. & -1.927586 \\
F-statistic & 4.552599 & Durbin-Watson stat & 2.037707 \\
Prob(F-statistic) & 0.054581 & & & \\
\hline \hline
\end{tabular}

Sumber :Data diolah menggunakan E-Views 8

Suatu variabel bebas dikatakan memiliki hubungan yang positif terhadap variabel terikat apabila memiliki nilai koefisien bertanda positif dan nilai signifikansinya pada probability $(\alpha)$ sebesar $0,01 * * * ; 0,05^{* *}$ dan $0,10 *$ untuk model ekonomi. 


\section{Pembahasan}

Dari data yang diperoleh maka persamaan regresi kemudian akan dianalisis dengan menggunakan hasil autoregresi model sbb :

$$
\text { PEt }=46.63303+3.713015 \mathrm{LGDPt}+0.080064 \mathrm{LJNTEt}+0.716804 \mathrm{LJPIt}
$$

Dari hasil estimasi yang diperoleh dapat dibuat sebuah interpretasi model atau hipotesa yang diambil dari hasil regres ini, bahwa variabel GDP, Jumlah nilai transaksi pada ECommerce dan Jumlah Pengguna internet berpengaruh positif dan signifikan terhadap pertumbuhan ekonomi di Indonesia. Tingkat signifikansi dari GDP dan JNTE pada $\alpha=10 \%$ sedangkan JPI justru lebih rendah lagi yakni pada $\alpha=5 \%$. Jika nilai koefisien variabel GDP dinaikkan sebesar 1 persen maka akan menambah nilai laju pertumbuhan ekonomi sebesar $3,71 \%$ atau GDP sangat berpengaruh besar terhadap pertumbuhan ekonomi dan sangat berdampak pada perekonomian di Indonesia. Variabel JNTE (Jumlah Nilai Transaksi $e$ Commerce) berpengaruh positif terhadap pertumbuhan ekonomi di Indonesia sebab, nilai koefisien variabel 0,080064 artinya apabila nilai JNTE (Jumlah Nilai Transaksi e-Commerce) dinaikkan sebesar 1 persen maka akan menambah nilai laju pertumbuhan ekonomi sebesar $0.08 \%$. Variabel JPI (Jumlah Pengguna Internet) berpengaruh positif terhadap laju pertumbuhan ekonomi di Indonesia sebab, nilai koefisien variabel dinaikkan sebesar 1 persen maka akan menambah nilai pertumbuhan ekonomi sebesar $0.72 \%$. Didalam hasil estimasi data dalam model regresi variabel-variabel yang mempengaruhi laju pertumbuhan ekonomi, terdapat nilai konstanta sebesar 46.63303 yang bernilai positif. Hal ini menunjukkan bahwa , tingkat nilai rata-rata laju pertumbuhan ekonomi berkecendrungan naik ketika variabel penjelas tetap.

Hasil Uji-t statistik dilakukan untuk melihat signifikan dari pengaruh variabel bebas secara individual terhadap variabel terikat dengan menganggap variabel bebas lainnya adalah konstan. Kita dapat melihat nilai probability dari t parsial jika nilai nya lebih kecil dari $\alpha 1 \%, \alpha 5 \%, \alpha 105 \%$ maka $\mathrm{H} 1$ diterima. Jika dilihat dari variabel Gross Domestic Product (GDP) nilai t parsial adalah 0,0681 dimana lebih kecil $(<)$ 0,10 sehingga H1 diterima. Variabel Jumlah Nilai Transaksi e-Commerce (JNTE) nilai t parsial adalah 0,0608 dimana lebih kecil (>) 0,10 sehingga $\mathrm{H} 0$ ditolak dan $\mathrm{H} 1$ diterima sehingga terdapat pengaruh yang positif dan signifikan terhadap pertumbuhan ekonomi, jika naiknya nilai dari GDP dan JNTE akan meningkatkan pertumbuhan ekonomi secara signifikan. Variabel Jumlah Pengguna Internet (JPI) nilai t parsial adalah 0,0379 dimana lebih besar (>) 0,05 sehingga $\mathrm{H} 0$ ditolak dan $\mathrm{H} 1$ diterima, maka terdapat pengaruh positif dan signifikan dengan pertumbuhan ekonomi. Jika bertambah banyak pengguna internet, maka dapat meningkatkan pertumbuhan ekonomi di Indonesia.

Uji F statistik bertujuan untuk pengujian signifikan semua variabel independen secara bersama-sama terhadap nilai variabel dependen. Dari hasil regresi pada variabel Gross Domestic Product (GDP), Jumlah Nilai Transaksi e-Commerce (JNTE), Jumlah Pengguna Internet (JPI) terhadap Laju Pertumbuhan Ekonomi di Indonesia maka nilai $F_{\text {probability }}$ adalah sebesar 0,05481 dimana lebih kecil (<) 0,10 atau $\alpha 10 \%$ sedangkan nilai $\mathrm{F}_{\text {hitung }}$ adalah sebesar 4.552599. Hal ini menunjukkan bahwa variabel independen secara bersama-sama berpengaruh signifikan terhadap variabel dependen Pertumbuhan Ekonomi. 
Karena uji heterokedastisitas dengan uji White menghasilkan nilai Prob. Chi-Square(6) pada Obs*R-squared sebesar 0.2577 lebih besar dari 5\% $(0,05)$ maka penelitian ini dinyatakan bersifat homokedastisitas atau terbebas dari heterokedastisitas.

Uji autokorelasi bertujuan untuk menguji apakah didalam suatu model regresi linear ada korelasi antara kesalahan penggunaan pada periode $\mathrm{t}$ dengan kesalahan pada periode $\mathrm{t}$ 1(sebelumnya) untuk menguji apakah suatu model terdapat autokorelasi. Dalam penelitian ini maka digunakan uji statistik Durbin Watson yaitu dengan cara melihat nilai (D-W) yang diperoleh. Pada model setelah dilakukan uji autoregressive diperoleh nilai Durbin Watson sebesar 2.037707 artinya pada model yang digunakan sudah terbebas dari masalah autokorelasi. Sehingga model bisa dipengaruhi oleh variabel bebas yang digambarkan oleh Gross Domestic Product (GDP), Jumlah Nilai Transaksi e-Commerce (JNTE) dan Jumlah Pengguna Internet (JPI). Dimana standart suatu model dikatakan tidak terdapat autokorelasi apabila nilai D-W yang diperoleh $1,54<\mathrm{dw}<2,46$.

\section{KESIMPULAN}

Berdasarkan pembahasan dan hasil penelitian yang telah dijabarkan pada bab-bab sebelumnya dapat di simpulkan bahwa terdapat pengaruh positif dan signifikan pada jangka waktu 10 tahun. Variabel GDP, JNTE dan JPI memiliki pengaruh yang positif dan signifikan terhadap pertumbuhan ekonomi, jika naiknya nilai dari GDP dan JNTE dan JPI akan meningkatkan pertumbuhan ekonomi secara signifikan. Meskipun variabel-variabel telah diregresi dengan menggunakan logaritma natural (Ln) namun semua menjadi signifikan pada $\alpha$ sebesar $10 \%$ dan 5\%. Jadi model yamg dibangun sudah relevan dan dapat divuktikan secara empris. Pertumbhan ekonomi pada era teknologi digitsal menjadi mesin penggerak pertumbuhan ekonomi dalam bentukaktivitas ekonomi yang dilakukan sehari-hari dalam menjalani jual beli dengan melakukan ntransaksi secara digutal dan berkomunikasi secara digital juga melalui web atau marketplace yang telah eksis di Indonesia.

Secara bersama-sama Gross Domestic Product (GDP), Jumlah Nilai Transaksi eCommerce ( JNTE), Jumlah Pengguna Internet (JPI) berpengaruh terhadap Laju Pertumbuhan Ekonomi Secara parsial, variabel Laju Pertumbuhan Ekonomi berpengaruh positif dan signifikan terhadap Gross Domestic Product (GDP, Jumlah Pengguna Internet (JPI). Jika terjadi peningkatan Gross Domestic Product (GDP, Jumlah Pengguna Internet (JPI) maka akan meningkatkan Laju Pertumbuhan Ekonomi di Indonesia.

\section{DAFTAR PUSTAKA}

Ariefianto, Moch. Doddy. 2012. Ekonometrika Esensi dan Aplikasi dengan menggunakan EViews. Jakarta:Erlangga.

Asosiasi Penyelenggara Jasa Internet. 2016. Hasil Survey 2016. www.apjii.or.id (diakses pada tanggal 5 januari 2018).

Bank Indonesia. 2016. Laporan Perekonomian 2016. www.bi.go.id (diakses pada tanggal 12 januari 2018)

Blanchard Olivier dan David R. Johnson. 2014. Makroekonomi. Edisi Keenam. Jakarta:Erlangga.

Case, E.Karl dan Ray C.Fair. 1996. Prinsip-Prinsip Ekonomi Makro. Edisi Kelima. Jakarta:Index.

Gujarati, Damodar. 2006. Dasar-dasar Ekonometrika. Edisi Ketiga Jilid 1. Jakarta:Erlangga.

IPrice. 2017. E-commerce Rewind Indonesia 2017. https://iprice.co.id (diakses pada tanggal 5 januari 2018). 
Jhingan M.L. 2008. Ekonomi Pembangunan dan Perencanaan. Edisi Keenam Belas. Jakarta:Rajagrafindo Persada.

Kasali Rhenald. 2017. Disruption. Tak Ada Yang Tak Bisa Diubah Sebelum Dihadapi Motivasi Saja Tidak Cukup. Jakarta:Gramedia Pustaka Utama.

Kominfo. 2016. Presentasi Pengguna Internet Untuk E-commerce Berdasarkan Umur Pada Tahun 2016. https://statistik.kominfo.go.id/ (diakses pada tanggal 5 januari 2018).

Mankiw, N.Gregory. 2006. Makroekonomi. Edisi Keenam. Jakarta:Erlangga.

Manurung Mandala Dan Prathama Rahardja. 2008. Pengantar Ilmu Ekonomi Edisi ke 3

Jakarta:Fakultas Ekonomi Universitas Indonesia.

Nachrowi, Nachrowi Djalal dan Hardius Usman. 2002. Penggunaan Teknik Ekonometri. Jakarta:Raja Grafindo Persada.

Phindyck, Robert S. dan Daniel L. Rubinfiels. 2012. Mikroekonomi. Edisi Kesembilan. Jakarta:Erlangga.

Singapore post. 2014. Indonesia's E-commerce Landscape 2014. Insight Into One Of Asia Pacific's Fastest Growing Markets. www.singpost.com (diakses pada tanggal 5 januari 2018).

Stillman David dan Jonah Stillman. 2018. Generasi Z. Memahami Karakter Generasi Baru Yang Akan Mengubah Dunia Kerja. Jakarta:Gramedia Pustaka Utama.

Todaro, Michael P. 1999. Pembangunan Ekonomi Di Dunia Ketiga. Edisi Keenam. Jakarta:Erlangga.

Varmaat, Shelly Cashman. 2007. Menjelajah Dunia Komputer Fundamental. Edisi Ketiga. Jakarta:Salemba.

Wong Jony. 2010. Internet Marketing For Beginners. Jakarta:Elex Media Komputindo. 